\title{
Atypical Employment Relationships in the New Hungarian Labour Code
}

\section{Introduction}

( ne of the main objectives $^{1}$ of the latest comprehensive labour law reform in Hungary was the flexibilisation of employment relationship, in order to increase the employment rate by promoting the competitiveness of employers ${ }^{2}$. The reform was finalised in the new Hungarian Labour Code (hereinafter: HLC) ${ }^{3}$, which is in line with the general trend of many recent labour law reforms ${ }^{4}$ across Europe ${ }^{5}$. This strategy is in contrast with some studies, which show that the former Labour Code ${ }^{6}$ was quite flexible in international comparison in the last two decades ${ }^{7}$. In spite

* Professor of Labour law, University of Szeged, Hungary.

1 The new (2012) Labour Code's core objectives were the following: (1) to achieve increase in employment rates via the promotion of employers' competitiveness by flexibilisation of employment protection; (2) to support enterprise adaptability and innovation; (3) to introduce clearer, simplified regulations; (4) to resolve contradictions; (5) to improve labour market flexibility; and (6) to align labour law with civil law.

2 As regards the EU Labour Law, the official reasoning of the draft Labour Code contained a remarkable - and very clear-cut - formulation of the related policy-approach: the Code attempts to make good use of the opportunities afforded by European labour law directives and to implement as flexible regulations as possible, adjusted to the needs of the local labour market. Thus, the EU labour law is seen not as a minimum, but rather as a maximum, when it comes to protection (see: A. Kun, National Report, Discussion Document - Hungary, ISLSSL XI European Regional Congress, 2014, p. 15).

3 Act I of 2012 on Labour Code.

${ }^{4}$ S. Clauwaert, I. Schömann, The Crisis and National Labour Law Reforms: a Mapping Exercise, Working Paper 2012.04, ETUI, 2012, atwww.etui.org (Retrieved 06.11.2014).

${ }^{5}$ See Green Paper on Modernising Labour Law, at http://europa.eu/legislation_summaries/employment_and_social_policy/eu2020/growth_and_jobs/c10312_en.htm (Retrieved 12.12.2014).

6 Act XXII of 1992 on Labour Code.

7 S. Cazes, A. Nesporova, Flexicurity: a Relevant Approach in Central and Eastern Europe, ILO, Geneva 2007, p. 147; and C. Wallace, Work Flexibility in Eight European Countries: A Cross-national Comparison, “Czech Sociological Review” 2003, vol. 39, No 6. 
of this analysis, the government declared that the Hungarian labour market shall be 'the most flexible in the world's, which will help to create one million new jobs in ten years 9 . In that, it aims to allow more flexible regulation of work to help firms regain competitiveness, while at the same time opening up the possibilities for cost cutting ${ }^{10}$. However, the legislators did not pay enough attention to job quality, which could be a significant approach to be tackled ${ }^{11}$. In this article, I intend to highlight the legal options of flexibilisation in the new Hungarian Labour Code.

The new atypical (flexible) employment relationships derive from three different sources. First, there are three new forms of atypical employment in the HLC: on-call work, job sharing and employee sharing ${ }^{12}$. Second, simplified (casual) employment is now regulated by the HLC, which had been considered an employment relationship earlier as well, however, it had been formerly regulated exclusively by a separate $\mathrm{Act}^{13}$. Third, outworkers' employment is now formally regulated by the Labour Code ${ }^{14}$ as an employment relationship, however, it is rather a legal relationship between the employment relationship and the civil law relationship belonging to the grey zone (economically dependent work). Nevertheless, the notion of self-employment ${ }^{15}$ is not defined in the Hungarian labour law ${ }^{16}$.

Below, I shall deal only with the atypical forms of employment relationship in the private sector which are incorporated into the HLC.

${ }^{8}$ http://index.hu/belfold/2014/10/12/.

${ }^{9}$ Government Programme 2010 (Nemzeti Megújulás Programja), p. 18 (at www.kormany.hu).

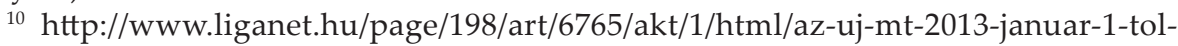
hatalyos-szovege.html (Retrieved 04.02.2013).

11 The 2014 OECD Employment Outlook paints a broad picture of job quality across the OECD countries, based on three essential dimensions: (1) earnings quality, (2) labour market security and (3) quality of the working environment. Hungary's overall performance ranks among the weakest of the OECD countries, even compared with its regional neighbours; available at: http://www.oecd.org/hungary/EMO-HUN-EN.pdf (Retrieved 21.11.2014).

12 Articles $193-195$ of the HLC.

13 Articles 201-203, other technical provisions are contained in Act 75 of 2010.

${ }^{14}$ Outworkers may be employed in jobs that can be performed independently and that is remunerated exclusively on the basis of the work done (Articles 198-200 of the 2012 HLC).

15 J. Hajdú, Social Security Protection of the Self-employed Persons in Hungary, [in:] Nagy Károly emlékkönyv, Szeged 2002, p. 175.

16 T. Gyulavári, A Bridge Too Far? The Hungarian Regulation of Economically Dependent Work, at: http://hllj.hu/files/pdfs/05\%20FES\%20study.pdf (Retrieved 16.12.2014). 


\section{Forms of atypical work in the Labour Code}

The new Hungarian Labour Code (2012) incorporates many atypical forms of employment relationship. These are the following: (1) homebased work, (2) telework, (3) casual work, (4) employee under employment relationship with public employer, (5) employment of incapacitated employee, (6) fixed-term contract, (7) part-time contract, (8) on-call contract, (9) job-sharing, (10) employee sharing, (11) agency work, and (12) employment relationships between school cooperatives and their members. Hereinafter, I shall discuss briefly each of them.

\subsection{Home-based worker}

A home-based worker is a person who works at home ${ }^{17}$ for a business and he/she cannot be categorised as a teleworker. The basic difference between telework and home-based work ${ }^{18}$ is the nature of work ${ }^{19}$ and the method of submission of the work result ${ }^{20}$.

According to the HLC, the employment contract for home-based workers must define: (1) the work performed by the employee, (2) the place of work, and (3) the method and extent of covering expenses. Furthermore, the home-based worker's working arrangements are flexible ${ }^{21}$.

Within the home-based work relationship, the employer's right of instruction is limited to specifying of the technique and work processes to be used by the employee. In the absence of an agreement to the contrary, the employee carries out the work using his/her own means ${ }^{22}$. The employer must determine the type of inspection ${ }^{23}$ and the shortest period of time between the notification and commencement of the inspection if conducted in a property designated as the place of work.

17 The employee's home or another place designated by the parties shall be construed as the place of work.

18 According to Section 198 of the HLC, home-based workers may be employed in jobs that can be performed independently and that is remunerated exclusively on the basis of the work done.

${ }_{19}$ As for the nature, home-based work is usually simple (usually) blue-collar type of work (e.g. sewing, fitting up, disassembling something, etc.), while telework is more complex (usually) white-collar work (e.g. of a journalist, translator, freelance expert, etc.).

${ }_{20}$ As for the submission of work, the employer brings the material of the work to the home-based worker, while in case of telework the work comes, is done and is sent back by IT equipment (a computer, telephone, Internet, etc. Nagy Károly emlékkönyv...).

${ }^{21}$ J. Ferencz, E. Göndör, T. Gyulavári, G. Kártyás, Munkajogi alapismeretek, ELTE Kiadó, Budapest 2013, p. 174.

${ }^{22}$ N.B. It seems to be an exception from the employment relationship because, usually, the employer provides the means and equipment necessary to work.

${ }^{23}$ However, the inspection may not bring unreasonable hardship on the employee or on any other person who is also using the property designated as the place of work. 
According to Section 200 of the HLC, the employee is reimbursed for the expenses actually incurred in connection with the work, or - if the expenses actually incurred cannot be determined - a fixed flat-rate sum shall be paid to the employee. However, payment of remuneration and expenses shall be withheld if the work done is deemed insufficient due to reasons within the employee's control ${ }^{24}$.

\subsection{Telework}

According to the HLC, teleworking' means activities performed on a regular basis at a place other than the employer's facilities, using computers and other means of information technology, where the end product is delivered by way of electronic means. In the employment contract the parties can agree on the worker's employment by means of teleworking. Under telework contract, the employee's working arrangements are flexible. However, the employer must provide access to the employee for entering its premises and to communicate with other workers.

The employer must provide all information to persons employed in teleworking as is provided to other employees. In addition to the regular information ${ }^{25}$, the employer must inform the teleworker about: (1) inspections conducted by the employer; (2) any restrictions as to the use of computing equipment or electronic devices; and (3) the department to which the employee's work is in fact connected.

The employer's right of instruction ${ }^{26}$ is limited solely to the definition of duties to be discharged by the employee. The employer may restrict the use of computing equipment or electronic devices it supplies solely to the work the employee performs on its behalf. An inspection concerning the completion of the work assignment will not constitute any right for the employer to inspect any information stored on the computing equipment of the employee used for discharging his/her duties, which are unrelated to the employment relationship. As regards the employer's right of access, the data necessary for control of the prohibition or restriction is considered to be related to obligations originating from the employment relationship. Basically, the employer can determine the type of inspection and the shortest period of time between the notification and commencement of the inspection if conducted in a property designated as the place of work. The inspection may not bring unreasonable hardship on the employee or on any other person who is also using the property designated as the place of work ${ }^{27}$.

${ }^{24}$ L. Pál, G. Lőrincz, A. Kozma, R. Pethő, Az új Munka Törvénykönyvének magyarázata, HVG-Orac, Budapest 2012, pp. 327-330.

${ }^{25}$ Section 46 of the HLC.

${ }^{26}$ Unless otherwise agreed.

${ }^{27}$ J. Hajdú, A. Kun (eds), Munkajog I, Patrocinium, Budapest 2012, p. 228-236. 


\subsection{Casual worker}

According to the HLC, casual work is called simplified employment. Casual work is governed by twofold legal provisions; first, under Sections 201-203 of the HLC and second, under Act LXXV of 2010 on Simplified Employment. Here, I shall deal only with the provisions of the HLC.

In practice, casual work usually lasts only for a few days ${ }^{28}$. Section 201 of the HLC states that employers and employees who are covered by the HLC may enter into simplified employment or occasional work relationships ${ }^{29}$. It is an important guarantee that an existing employment contract may not be modified by the parties to conclude a simplified employment or occasional work relationship.

There are some most important characteristics of casual work. Unlike a regular employment contract, the parties of a simplified employment relationship can set up a legal relationship by oral agreement $t^{30}$. The employment relationship shall be considered concluded upon fulfilment of the notification requirement specified by law. The date of the notification will be the starting date of the employment relationship. The commencement of the employment relationship is not applicable ${ }^{31}$. The casual worker cannot be ordered to temporarily fulfil other work assignment ${ }^{32}$. The legal consequences for the employee's wrongful breach of duty do not apply to the casual worker ${ }^{33}$. There is no need to provide a written assessment of the employee's work if the employment relationship has lasted for at least one year ${ }^{34}$. The provisions relating to scheduled working time on Sundays or public holidays are not applicable ${ }^{35}$. The allocation of vacation time is not applicable ${ }^{36}$. The provisions of maternity leave, leave of absence without pay are not applicable ${ }^{37}$. The provisions of fixed-term employment relationships are not applicable ${ }^{38}$. The provisions relating to executive employees are not applicable to casual workers ${ }^{39}$. The certificates

28 That is the reason why special provisions are required besides the labour law in force.

${ }_{29}$ However, any employment contract for simplified employment shall be considered null and void if the parties are engaged under an employment relationship at the time it has been concluded.

${ }^{30}$ However, when concluding the employment contract, the parties may use the model employment contract specified by law.

31 Section 49, para. (2) of the HLC.

32 Section 53 of the HLC.

${ }^{33}$ Section 56 of the HLC.

${ }^{34}$ Section 81 of the HLC.

35 Section 101 of the HLC.

36 Sections 122-124 of the HLC.

37 Sections 126-133 of the HLC.

38 Section 192, para. (4) of the HLC.

39 Sections $208-211$ of the HLC. 
referred to in Section 80 of the HLC need not be provided upon termination of the employment relationship. Finally, the daily working time may be arranged based on an irregular work schedule, regardless of any working time banking arrangement or payroll period arrangement ${ }^{40}$.

\subsection{Employee under employment relationship with the public employer}

Since 2009, separate regulations ${ }^{41}$ have been applicable to public employers ${ }^{42}$. However, employees in such relationships are not civil or public servants. They are still under the personal scope of the HLC. The aim of the special provisions is mainly to protect public property ${ }^{43}$.

There are some special protecting provisions in the HLC. (1) In the collective agreement or in the agreement of the parties: (a) no derogation is allowed from the duration of the notice period, and (b) no derogation is allowed either from provisions of severance payment. (2) In employment relationships with public employers, the full daily working time may not be reduced below the regular daily working time, unless it is deemed necessary in order to prevent any health impairment or harmful effects. (3) Basically, the HLC's chapters on industrial rela680 tions $^{44}$ are applicable. (4) The entity exercising ownership rights shall have powers to establish performance requirements for the executive employees, including the related performance-based wage and other benefits. (5) A non-competition agreement may be concluded with executive employees for a period up to one year, subject to approval by the entity exercising ownership rights. The entity exercising ownership rights may define the jobs in respect of which a non-competition agreement can be concluded, and may prescribe further conditions. However, the consider-

${ }^{40}$ L. Bodnár, Az új Munka törvénykönyve munkavállalóknak, Complex-Volters Kluwer, Budapest 2012, p. 108.

${ }^{41}$ This is Act CXXII of 2009 on the Economical Operation of Public Business Organisations.

${ }^{42}$ Public employer means a public foundation or a business association in which the state, a municipal government, an association of municipal governments vested with legal personality, a multi-purpose micro-region association, a development council, a minority self-government body, an association of minority self-government bodies vested with legal personality, a budgetary agency or a public foundation has majority control, either by itself or collectively.

${ }^{43}$ This is shown by the fact that in the HLC dispositivity is typical in general, in the case of public employers, regulations which do not allow derogations (cogency) are dominant.

${ }^{44}$ Particularly Chapter XIX on General Provisions on Industrial Relations, Chapter XX on Work Councils and Chapter XXI on Trade Unions. 
ation stipulated in the non-competition agreement may not - for the duration of the agreement - exceed fifty per cent of the absentee pay due for such period ${ }^{45}$.

\subsection{Employment of an incapacitated employee}

This is a new provision of the HLC. The previous Labour Code (1992) did not allow the employment of incapacitated persons ${ }^{46}$ in an employment relationship ${ }^{47}$.

There are two fundamental factors underlying this change in labour law regulations:

(1) The Convention on the Rights of Persons with Disabilities adopted by the UN on 13 December 2006 and the respective Optional Protocol, which Hungary was the first state in the world to ratify and to promulgate in Act XCII of $2007^{48}$.

(2) In its Decision No 39/2011 (V.31), the Constitutional Court stated the breach of the Constitution by failing to establish the statutory regulations of the employment relationship of incapacitated persons in the effective law.

As for guarantee, according to Section 212 of the HLC, incapacitated workers may conclude employment relationships only for jobs which they are capable to handle on a stable and continuous basis in the light of their medical condition ${ }^{49}$. The functions of the employee's job will be determined by definition of the related responsibilities in detail. The employee's work will be supervised continuously so as to ensure that the requirements of occupational safety and health are satisfied ${ }^{50}$. The provisions of Chapter XIV on Employees' Liability for Damages of the HLC will not apply to such employees. However, in such case, the provisions pertaining to young workers shall apply.

${ }^{45}$ G. Berke, G. Kiss (eds), Kommentár a munka törvénykönyvéhez, Complex-Volters Kluwer, Budapest 2012, pp. 502-505.

46 The concept of incapacity is defined in the Civil Code. Incapacity may be based on: (1) age, (2) being under conservatorship, and (3) actual situation.

47 http://www.profession.hu/cikk_rovid_hirek/20121119/a-gondoksag-alatt-allok-isdolgozhatnak/1755 (Retrieved 13.05.2013).

${ }^{48}$ http://www.e-epites.hu/jogszabalyok/2007-evi-xcii-torveny-a-fogyatekossaggal-elo-szemelyek-jogairol-szolo-egyezmeny (Retrieved 17.07.2013).

${ }^{49}$ Special medical examination will cover the employee's ability to handle the functions of the job.

${ }^{50}$ L. Pál, G. Lőrincz, A. Kozma, R. Pethő, Az új Munka Törvénykönyvének..., p. 363-367. 


\subsection{Fixed-term contract}

According to the HLC, the contract established for an indefinite period of time is considered typical. Thus, contracts without a definite specification of time should be regarded as established for an indefinite period ${ }^{51}$.

The period of fixed-term employment shall be determined according to the calendar or by other appropriate means. If the duration of an employment relation is not determined by the calendar, the employer is obliged to inform the employee of the expected duration of employment. Where an employment relation is subject to official approval, it may only be for the duration specified in the authorization.

The duration of a fixed-term employment relation may not exceed five years, including the duration of an extended relation and that of another fixed-term employment created within six months of the termination of the previous fixed-term employment relation. By way of derogation from the above, if the particular authorization is extended, the duration of the new fixed-term employment relation may exceed five years together with the duration of the previous employment relation.

The type of contract underlying an employment relationship may not be chosen with a view to restricting or violating the provisions that provide for the protection of the employee's rightful interests ${ }^{52}$.

In the case of part-time employment, all payments made to the employee in exchange for work, whether in money or in kind and whether directly or indirectly, must be provided in accordance with the length of time of work performed if remuneration is contingent upon the amount of working time ${ }^{53}$.

\subsection{Part-time contract}

According to the HLC, a full-time employment usually encompasses 40 hours of work per week, 8 hours per day. The employer and the employee can individually agree on shorter or longer working hours. If no working time is indicated in the contract, a full-time employment is estab-

51 The 2014 OECD Employment Outlook also puts a spotlight on labour market duality. Historically, this has been less of a concern in Hungary, as the share of fixed-term contracts is considerably lower than the OECD average. However, the steady increase in their use - especially among newly signed work contracts where there has been an almost 10 percentage point increase since 2006 - calls for further monitoring and assessment. See: http://www.oecd.org/hungary/EMO-HUN-EN.pdf (Retrieved 21.11.2014).

${ }^{52} \mathrm{Cf}$. footnote 52 above.

${ }^{53}$ K. Dudás, T. Gyulavári, I. Horváth, N. Hős, G. Kártyás, M. Kulisity, A. Kun Attila, Z. Petrovics, Munkajog, ELTE Eötvös Kiadó, Budapest 2012, pp. 412-416. 
lished. Part-time employment has to be indicated in the contract. Part-time employees are entitled to reimbursement of costs and paid vacation equally to full-time employees. Their remuneration is proportional ${ }^{54}$.

\subsection{On-call contract}

According to Section 193 of the HLC, part-time workers employed under employment contract in jobs for up to six hours a day can work at times deemed necessary to best accommodate the function of their jobs. In this case, the duration of working time banking may not exceed four months. The employer will inform the employee of the time of working at least three days in advance ${ }^{55}$.

\subsection{Job-sharing}

According to Section 194 of the HLC, the employer may conclude an employment contract with several workers for carrying out the functions of a job jointly. Where any one of the employees to the contract is unavailable, another worker to the contract shall fill in and perform the functions of the job as ordered. The scheduling of work is governed by the provisions on flexible working arrangements. Wages are distributed among the employees equally, unless there is an agreement to provide otherwise.

The employment relationship will cease to exist when the number of employees is reduced to one. In this case, the employer is liable to pay the worker affected absentee pay covering a period that would otherwise be due in the event of dismissal by the employer; furthermore, the rules on severance pay shall also apply ${ }^{56}$.

\subsection{Employee sharing}

According to Section 195 of the HLC, several employers may conclude an employment contract with one worker for carrying out the functions of a job. The employment contract will clearly indicate the employer designated to pay the employee's wages. The liability of employers in respect of the employee's labour-related claims will be joint and several. The employment relationship may be terminated by either of the employers or by the employee. The employment relationship shall cease to exist when the number of employers is reduced to one ${ }^{57}$.

54 J. Cséffán, A munka törvénykönyve és magyarázata, Szegedi Rendezvényszervező Kft., Szeged 2012, p. 375.

${ }_{55}$ L. Bodnár, Az új Munka törvénykönyve munkavállalóknak..., p. 105.

${ }^{56}$ G. Berke, G. Kiss (eds), Kommentár a munka törvénykönyvéhez..., p. 490.

${ }^{57}$ L. Bodnár, Az új Munka törvénykönyve munkavállalóknak..., p. 105. 


\subsection{Agency work}

According to the HLC, temporary agency work means a situation when an employee is hired out by a temporary work agency to a user enterprise ${ }^{58}$ for remunerated temporary work, provided there is an employment relationship between the worker and the temporary work agency (placement) $)^{59}$.

The content of the agreement ${ }^{60}$ between the placement agency and the user enterprise will specify the material conditions of placement ${ }^{61}$, and the sharing of the employer's rights. The temporary work agency must be required to cover all employment-related expenses, such as the employee's costs of travel and the costs of a medical examination if one is required for employment. The agreement must be made in writing ${ }^{62}$. The user enterprise shall not have the right to order a temporary agency worker to work at another employer.

58 According to Section 215 of the HLC, the following may function as temporary work agencies:

(1) a company established in an EEA Member State that is authorized under national law to engage in the activities of temporary work agencies, or

(2) a business association established in Hungary whose members have limited lia684 bility, or

(3) a cooperative society in respect of employees other than its members.

In addition, the agency must be registered by the government employment agency. Where a temporary-work agency is excluded from the register, the provisions on invalidity will apply with regard to employment contracts.

${ }_{59}$ G. Kártyás, Munkaerö-kölcsönzés: mi változott? (I-II. Rész) at: http://ado.hu/rovatok/ munkaugyek/munkaero-kolcsonzes-mi-valtozott-ii-resz (Retrieved 17.07.2013.).

${ }^{60}$ An agreement between the temporary work agency and the user enterprise will be null and void if: (1) the temporary work agency and the user enterprise are affiliated by way of ownership in part or in whole, or (2) at least one of the two employers holds some percentage of ownership in the other employer, or (3) the two employers are connected through their ownership in a third organization.

${ }^{61}$ The employment contract must contain a clause indicating that it was concluded for the purpose of temporary work, and also must contain a description of the work and the basic wage.

${ }^{62}$ Before the assignment, the temporary work agency must provide to the employee with the following information in writing: (1) the identification data of the user enterprise, (2) the beginning date of the assignment, (3) the place of work, (4) the normal course of work at the user enterprise, (5) the person exercising employer's rights on the user enterprise's behalf, and (6) the particulars on travel to work, room and board.

The user enterprise must inform the temporary work agency in writing of its: (1) normal course of work, (2) the person exercising employer's rights, (3) the manner and the timeframe within which to supply the information necessary for the payment of wages, (4) the qualification requirements pertaining to the work in question, and all aspects that are considered significant in terms of the employment of the worker in question. 
The basic working and employment conditions of temporary agency workers will be, for the duration of their assignment, at least those available to the workers employed by the user enterprise under employment relationship.

A TWA agreement is considered invalid if it contains a clause to ban or restrict any relationship with the user enterprise following termination of the employment relationship on any grounds, or if it contains a clause to stipulate the payment of a fee by the employee to the temporary work agency for the assignment, or for entering into a relationship with the user enterprise.

The basic working and employment conditions will, in particular, cover: (1) the protection of pregnant women and nursing mothers, (2) the protection of young workers, (3) the amount and protection of wages, including other benefits, and (4) the provisions on equal treatment. As regards the payment of wages and other benefits, the provisions on equal treatment must be respected ${ }^{63}$.

The duration of assignment may not exceed five years, including any period of extended assignment and re-assignment within a period of six months from the time of termination of the employee's previous employment, irrespective of whether the assignment was made by the same or by a different temporary work agency ${ }^{64}$.

In connection with any damage caused by the employee, the user enterprise may demand compensation from the employee. By agreement between the temporary-work agency and the user enterprise, the provisions of civil law on liability for damages caused by the employee will apply. In the application of the provisions of civil law on the employer's liability for damages caused by the employee, the user enterprise will be construed as the employer, unless there is an agreement to the contrary between the temporary-work agency and the user enterprise. The user enterprise and the temporary-work agency will be subject to joint and several liability for any damages caused to the employee while on assignment ${ }^{65}$.

Employment may only be terminated by the placement agency ${ }^{66}$. The termination of the assignment will be construed as a reason in connection with the temporary work agency's operation. The notice period is fifteen days ${ }^{67}$.

${ }^{63}$ K. Dudás, T. Gyulavári, I. Horváth, N. Hős, G. Kártyás, M. Kulisity, A. Kun, Z. Petrovics, Munkajog..., p. 422-436.

${ }^{64}$ According to Section 216 of the HLC, the assignment of workers is not allowed: (1) in the cases specified by the relevant employment regulations, (2) with a view to replacing workers on strike, and (3) beyond the five years duration.

${ }^{65}$ J. Hajdú, A. Kun (eds), Munkajog I..., p. 236-255.

${ }_{66}$ The user enterprise will notify the temporary-work agency in writing concerning any infringement on the employee's part within five working days from the time of gaining that knowledge. The time limit commences upon delivery of the information.

${ }^{67}$ If termination is effected by the temporary-work agency, the employee will be exempted from work during the notice period, unless otherwise agreed. 
The employee may terminate the employment relationship without notice in case of infringement by the user enterprise. The employee must submit the notice for termination of the employment relationship to the temporary-work agency.

\subsection{Employment relationships between school cooperatives and their members}

A new Chapter XVII of the HLC determines the special rules of work performance relating to the work of members of school cooperatives with third-party employers. This is a special form of agency work in Hungary $^{68}$. According to the HLC, a school cooperative (employer) and its fulltime student (employee) may enter into a fixed-term employment relationship so as to permit such student to perform work at a third party (customer) with a view to supplying services to such third party ${ }^{69}$.

The customer is entitled to give instructions to the employee. The customer must cooperate with the employer, in particular, by providing access for the employer's representative to the place of work and by making available information for the employer in connection with issues concerning the work. During the period of work performed by the employee, the customer must exercise and discharge the employer's rights and obligations relating to compliance in the areas such as: (1) occupational safety and health, (2) the employment of women, young workers and persons with reduced ability to work, and (3) working time, rest period and the records thereof.

In connection with any damage caused by the employee, the customer may demand compensation from the employee in accordance with the HLC. In such a case, by agreement between the employer and the customer, the provisions of civil law on the employer's liability for damages caused by an employee will apply. For any damages caused to the employee during work performed for the customer, the employer and the customer will be subject to joint and several liability ${ }^{70}$.

The employment relationship can be terminated at the time when cooperative membership ceases to exist.

${ }^{68}$ G. Berke, G. Kiss (eds), Kommentár a munka törvénykönyvéhez..., p. 539-543.

${ }^{69}$ Section 223 of the HLC.

70 A. Kun Attila, B. Rossu, Youth Employment and Relevant Labour Market Programmes in Hungary, [in:] T. Fashoyin, M. Tiraboschi, P. Manzella, L. Rustico (eds), Productivity, Investment in Human Capital and the Challenge of Youth Employment, ADAPT Labour Studies Book-Series, International School of Higher Education in Labour and Industrial Relations, Cambridge Scholars Publishing, Cambridge 2011, pp. 241-271. 


\section{Summary}

In Hungary, the role of flexible working arrangements has been given increased attention as a possible labour market solution to the economic crisis. The proportion of atypical, for example part-time employment, has increased compared to the level before the crisis, but widespread use is still untypical ${ }^{71}$.

As a summary, it can be concluded that, as a result of the crisis, the proportion of those in forced atypical employment has increased in Hungary, too, and employment has clearly been shifted towards satisfying the needs and requirements of the demand side. The intention behind the adoption of the new Labour Code was obviously to strengthen this process.

\section{Bibliography}

Berke G., Kiss G. (eds), Kommentár a munka törvénykönyvéhez, Complex-Volters Kluwer, Budapest 2012.

Bodnár L., Az új Munka törvénykönyve munkavállalóknak, Complex-Volters Kluwer, Budapest 2012.

Cazes S., Nesporova A., Flexicurity: a Relevant Approach in Central and Eastern Europe, ILO, Geneva 2007.

Clauwaert S., Schömann I., The Crisis and National Labour Law Reforms: a Mapping Exercise, Working Paper 2012.04., ETUI, 2012, at www.etui.org.

Cséffán J., A munka törvénykönyve és magyarázata, Szegedi Rendezvényszervező Kft., Szeged 2012.

Dudás K., Gyulavári T., Horváth I., Hős N., Kártyás G., Kulisity M., Kun A., Petrovics Z., Munkajog, ELTE Eötvös Kiadó, Budapest 2012.

Ferencz J., Göndör E., Gyulavári T., Kártyás G., Munkajogi alapismeretek, ELTE Kiadó, Budapest 2013.

Green Paper on Modernising Labour Law, at http://europa.eu/legislation_summaries/employment_and_social_policy/eu2020/growth_and_jobs/c10312_en.htm.

Hajdú J., Social Security Protection of the Self-employed Persons in Hungary, [in:] Nagy Károly emlékkönyv, Szeged 2002.

Hajdú J., Kun A. (eds), Munkajog I, Patrocinium, Budapest 2012.

Kun A., Rossu B., Youth Employment and Relevant Labour Market Programmes in Hungary, [in:] T. Fashoyin, M. Tiraboschi, P. Manzella, L. Rustico (eds), Productivity, Investment in Human Capital and the Challenge of Youth Employment, ADAPT Labour Studies BookSeries, International School of Higher Education in Labour and Industrial Relations, Cambridge Scholars Publishing, Cambridge 2011.

Pál L., Lőrincz G., Kozma A., Pethő R., Az új Munka Törvénykönyvének magyarázata, HVG-Orac, Budapest 2012.

Wallace C., Work Flexibility in Eight European Countries: A Cross-national Comparison, "Czech Sociological Review" 2003, vol. 39, No 6.

${ }^{71}$ For example, employers increasingly rely on fixed-term employment, too. As a result, the number of persons employed in this form rose from 7.8 per cent in 2008 to 10.8 percent in 2013. 


\section{Nietypowe stosunki pracy w nowym węgierskim kodeksie pracy}

\section{Streszczenie}

Zakres nietypowego zatrudnienia $\mathrm{w}$ węgierskim prawie pracy zmienił się znacząco od wejścia w życie 1 lipca 2012 r. nowego Kodeksu pracy. Podstawowym celem zmian było stworzenie elastycznego systemu prawa pracy, odpowiadającego wyzwaniom rynkowym, a także potrzebom sektora usług oraz sektora małych i średnich przedsiębiorstw. Na Węgrzech zasięg nietypowych form zatrudnienia (np. zatrudnienia $\mathrm{w}$ niepełnym wymiarze, zatrudnienia terminowego, telepracy i in.) jest dość niski. Dlatego Kodeks pracy wprowadził więcej elastycznych regulacji odnoszących się do nietypowych form zatrudnienia, umożliwiających stronom lepsze zaspokojenie ich potrzeb. Nowy Kodeks przewiduje wiele nietypowych form stosunków pracy. Należą do nich: (1) praca nakładcza, (2) telepraca, (3) praca doraźna, (4) zatrudnienie przez publicznego pracodawcę, (5) zatrudnienie osób ubezwłasnowolnionych, (6) umowy terminowe, (8) praca na wezwanie, (9) dzielenie się praca, (10) dzielenie pracownika, (11) praca tymczasowa, (12) stosunki pracy między spółdzielniami szkolnymi i ich członkami. Autor zwięźle charakteryzuje każdą z tych form zatrudnienia. 